\title{
PEMENUHAN HAK-HAK PEKERJA MIGRAN ASAL SULAWESI SELATAN DI MALAYSIA DALAM PERSPEKTIF EKONOMI POLITIK ${ }^{1}$
}

\author{
Achmad Zulfikar \\ Perkumpulan Peneliti dan Pegiat Pekerja Migran Indonesia (P4MIGI); \\ Program Studi Ilmu Hubungan Internasional Universitas Fajar \\ Surel korespondensi: apa@kabarfikar.com
}

\begin{abstract}
Abstrak
Hak untuk bekerja harus dipenuhi oleh pemerintah sebagai tanggungjawab atas jaminan HAM warga negara sesuai UUD NRI 1945 pasal 27 ayat (2). Penelitian ini bertujuan menggambarkan pemenuhan hak-hak pekerja migran asal Sulawesi Selatan di Malaysia berdasarkan UU No. 39 Tahun 2004 pada masa pra-penempatan dam masa penempatan. Penelitian ini dilaksanakan di Provinsi Sulawesi Selatan, Indonesia dan Tawau, Sabah, Malaysia. Metode yang digunakan adalah kualitatif dengan pendekatan studi kasus. Data diperoleh melalui wawancara dan studi pustaka. Data dianalisis menggunakan teknik reduksi data, penyajian data dan penarikan kesimpulan. Hasil penelitian menunjukkan bahwa pemenuhan hak-hak pekerja migran asal Sulawesi Selatan di Malaysia pada masa pra-penempatan dan masa penempatan yang dilaksanakan dengan benar akan signifikan bagi peningkatan ekonomi tenaga kerja Indonesia/pekerja migran Indonesia (TKI/PMI), negara penempatan (Malaysia) dan negara asal (Indonesia). Semakin tinggi tingkat pemahaman seseorang terkait prosedur yang legal, semakin berkurang TKI/PMI yang menempuh jalur ilegal/non-prosedural
\end{abstract}

Kata kunci: Ekonomi Politik, Hak Asasi Manusia, Pekerja Migran, Sulawesi Selatan, Malaysia

\begin{abstract}
The right to work has to be fulfilled by the government as the responsibility for the human rights guarantees for citizens according The 1945 Constitution of the Republic of Indonesia (UUD NRI 1945) article 27 section (2). The aims of this research were to describe and analyze rights fulfillment of migrant workers from South Sulawesi in Malaysia based on Regulations No. 39 Year 2004 on pre-placement phase and on placement phase. The research was carried out in South Sulawesi Province of Indonesia and Tawau, Sabah, Malaysia. The research employed a qualitative method and a case study approach. Data were gathered through interviews and library research. Data were analyzed using data reduction, data presentation, and conclusion drawing. The results showed that the right fulfillment of migrant workers from South Sulawesi in Malaysia both during pre-placement and after placement contributed significantly to economic improvement benefited both Indonesia as supplying country and Malaysia as placement country. The better the awareness regarding legal procedure the smaller chance for the migrants/workers to make use of illegal procedure.
\end{abstract}

Keyword : Political Economy, Human Rights, Migrant Workers, South Sulawesi, Malaysia

\section{PENDAHULUAN}

Bekerja merupakan hak setiap warga negara yang dijamin oleh UUD NRI 1945. Hak ini dinyatakan dalam pasal 27 ayat (2) yakni setiap Warga Negara Republik Indonesia berhak atas pekerjaan dan penghidupan yang layak bagi kemanusiaan. Pemerintah Indonesia saat ini belum mampu untuk menjalankan tugasnya untuk membuka akses lapangan pekerjaan dengan

\footnotetext{
${ }^{1}$ Dalam proses review di Jurnal Power in International Relations yang diterbitkan Universitas Potensi Utama, Medan. Naskah diunggah sebagai pre-prints untuk mendapatkan masukan publik. Apabila pembaca ingin memberi masukan, silahkan hubungi penulis.
} 
optimal. Rendahnya daya serap lapangan kerja di dalam negeri mengakibatkan terjadinya migrasi pekerja Indonesia ke luar negeri yang pelakunya disebut sebagai Tenaga Kerja Indonesia/Pekerja Migran Indonesia. Migrasi kerja ke luar negeri ini memberikan peluang dan harapan bagi TKI/PMI untuk mendapatkan penghasilan yang lebih besar dan kehidupan yang lebih baik. Warga negara Indonesia yang berkeinginan untuk mencari pekerjaan luar negeri mendorong pemerintah Indonesia untuk merumuskan UU No. 39 Tahun 2004 tentang penempatan dan perlindungan TKI. Hal ini sebagai upaya untuk memastikan bahwa pekerja migran (TKI/PMI) yang ditempatkan mendapatkan perlindungan di negara penempatan.

Pelaksanaan penempatan dan perlindungan TKI/PMI di luar negeri merupakan sinergi antara pemerintah pusat dan pemerintah daerah untuk membuka lapangan kerja bagi warganya ke luar negeri. Badan Nasional Penempatan dan Perlindungan Tenaga Kerja Indonesia (BNP2TKI) merilis data penempatan TKI berdasarkan provinsi Sulawesi Selatan yang menjadi wilayah yang diteliti berada pada posisi kesepuluh. Provinsi ini terdiri atas 24 kabupaten/kota dengan angka penempatan yang signifikan menurut catatan Balai Pelayanan Penempatan dan Perlindungan Tenaga Kerja Indonesia (BP3TKI) Makassar meliputi Gowa, Bantaeng, Bulukumba, Jeneponto, Makassar dan Pinrang. Sedangkan negara penempatan/tujuan TKI di posisi teratas selama empat tahun terakhir (2012-2015) dengan persentase 90 persen adalah Malaysia. BP3TKI juga menyatakan bahwa pekerja migran asal Sulsel mayoritas bekerja di sektor perkebunan.

Sektor perkebunan yang menjadi lapangan kerja pekerja migran asal Sulawesi Selatan perlu mendapatkan perhatian yang serius dari para pihak, dikarenakan minat pada sektor ini yang tinggi. Menurut Chaniago dari Asosiasi Pengusaha Indonesia (Apindo) dikutip dari Detik Finance (2014), menyatakan bahwa pekerja sektor perkebunan di Malaysia seperti di Sabah dan Serawak rata-rata mendapatkan gaji sekitar 800 ringgit atau setara dengan Rp 2,9 juta per bulan. Tetapi justru profesi pekerja di sektor perkebunan sama sekali tidak dilirik oleh masyarakat Malaysia. Bagi mereka, menjadi pekerja perkebunan tidak akan mencukupi kebutuhan hidupnya setiap bulan. Masyarakat Malaysia lebih memilih mencari pekerjaan di pusat kota Malaysia seperti Penang dan Johor, karena upah yang jauh lebih besar yakni minimal 900 ringgit atau sekitar Rp. 3,2 juta/bulan bergantung negosiasi gaji antara pekerja dan pengusaha.

Islam (2013), memandang bahwa Indonesia dan Malaysia memiliki hubungan yang dalam dan terikat karena alasan historis, geografis, ekonomi dan kultural. Dalam aspek historis, sejak masa kolonial Inggris menguasai Malaya, penduduk Indonesia sudah 
melakukan migrasi bahkan sampai menetap. Dalam aspek ekonomi dikarenakan terjadinya interaksi antara masyarakat, maka perniagaan (jual beli) merupakan salah satu upaya yang dilakukan untuk memenuhi kebutuhan hidupnya. Kemudian dalam aspek kultural, Indonesia dan Malaysia memiliki kemiripan yang dikuatkan sebagai simbol bangsa "serumpun melayu". Kesadaran identitas sebagai sesama Melayu seharusnya saling mengisi dalam migrasi pekerja karena keduanya berpotensi besar mengembangkan hubungan yang saling menguntungkan (mutual benefits) baik dalam bidang ekonomi maupun politik, khususnya dalam sektor ketenagakerjaan.

Caporaso dan Levine (2008), menyatakan bahwa ekonomi politik secara definitif dimaknai sebagai interrelasi di antara aspek, proses, dan institusi politik dengan kegiatan ekonomi (produksi, investasi, penciptaan harga, perdagangan, konsumsi dan lain sebagainya). Yustika (2009), mengungkap bahwa istilah ekonomi politik (political economy) pertama kali diperkenalkan oleh Antoyne de Montchètien (1575-1621) dari Perancis, dalam bukunya yang bertajuk Tretise on Political Economy. Sedangkan dalam bahasa Inggris penggunaan istilah ekonomi politik terjadi pada 1767 lewat publikasi Sir James Steuart (1712-1789) berjudul Inequiry into the Principles of Political Economy.

Arifin dan Rachbini dalam Deliarnov (2006), menyatakan bahwa penelusuran yang mendalam tentang analisis ekonomi politik kelembagaan biasanya didekati dengan format dan pola hubungan antara swasta, masyarakat, organisasi buruh, partai politik, pemerintah, lembaga konsumen dan sebagainya. Keberadaan pekerja migran Indonesia sebagai individu yang berorientasi terhadap maksimalisasi keuntungan. Orientasi ini seringkali melanggar aturan-aturan yang telah ditetapkan sehingga penyimpangan-penyimpangan seperti TKI/PMI ilegal atau tidak berdokumen di negara penempatan hingga WNI yang menjadi korban perdagangan manusia terjadi. Oleh karena itu dibutuhkan sinergitas dan optimalisasi peran pemerintah, swasta dan masyarakat sipil untuk memenuhi hak-hak pekerja migran Indonesia, lebih spesifik pekerja migran asal sulawesi selatan.

Penelitian ini memiliki nilai kebaruan (novelty) dari sisi pendekatan. Pendekatan yang digunakan dalam penelitian ini menggunakan analisis ekonomi politik, secara spesifik ekonomi politik kelembagaan. Di samping itu, lokasi penelitian yang lebih spesifik ke Sulawesi Selatan (Sulsel). Adapun penelitian yang relevan antara lain Kardina (2015), yang meneliti Pelanggaran Malaysia terhadap Standar HAM CEDAW dalam Isu Kekerasan Migrant Domestic Worker Indonesia, penelitian tersebut menyimpulkan bahwa kebijakan Malaysia dalam menangani masalah pekerja migran Indonesia (MDW) masih mengandung 
unsur diskriminasi terhadap perlindungan HAM yang merupakan pelanggaran prinsip konvensi. Selanjutnya, Zulfikar (2015) dalam penelitian mengenai Rasionalitas Ekonomi Politik dalam Ratifikasi Konvensi Internasional Perlindungan Hak Pekerja Migran menyimpulkan bahwa pemerintah Indonesia meratifikasi konvensi internasional perlindungan hak pekerja migran atas pertimbangan aspek ekonomi dan politik. Kemudian, Husna (2013), meneliti Kebijakan Pemerintah dalam Penempatan dan Perlindungan TKI, penelitian tersebut menyimpulkan bahwa sebagian permasalahan penempatan TKI yang terjadi disebabkan oleh regulasi yang kurang.

Penelitian relevan lainnya diteliti oleh Masrie (2015) mengenai Analisis Kebijakan Susilo Bambang Yudhoyono dalam Menangani Masalah Tenaga Kerja Indonesia di Malaysia dalam Perspektif Ekonomi Politik. Penelitian ini mengkaji peluang dan tantangan hubungan bilateral Indonesia-Malaysia di bidang ketenagakerjaan di era kedua pemerintahan Susilo Bambang Yudhoyono (2009-2014), dan kajian mengenai strategi kebijakan ekonomi politik yang diterapkan pemerintahan Susilo Bambang Yudhoyono (SBY) dalam menangani berbagai kasus tenaga kerja Indonesia di Malaysia. Hasil penelitian menunjukkan bahwa permasalahan TKI di Malaysia sangat kompleks dan melibatkan berbagai elemen yang saling terkait. Di masa pemerintahan Susilo Bambang Yudhoyono (SBY), secara politik, persoalan TKI belum banyak mengalami perubahan sebagaimana kasus yang dialami Winfaidah, wanita asal Lampung yang menjadi korban penyiksaan majikannya di Penang dan Nurul Aidah yang ditemukan tewas dalam bagasi mobil majikannya. Secara ekonomi, keberadaan TKI memberikan sumbangsih yang cukup signifikan terhadap perekonomian dalam negeri dengan pemasukan devisa yang dihasilkan dari remitansi yang dikirimkan TKI, bisa mencapai Rp. 60 triliun (US\$ 6,615 miliar) setiap tahunnya. Sedangkan strategi yang diterapkan SBY, melalui strategi politik dan ekonomi dengan pendekatan ekonomi politik.

Selanjutnya, penelitian dari Jaafar (2015) dalam Badu (2015) mengkaji tentang Kebijakan terhadap Pekerja Asing: Tantangan dalam Hubungan Indonesia-Malaysia. Penelitian ini mengkaji dua sisi pemerintah yakni Malaysia dan Indonesia. Penelitian ini menyimpulkan permasalahan pekerja migran Indonesia di Malaysia tidak akan pernah selesai, jika permasalahan ini tidak diselesaikan oleh kedua pihak, maka kedua negara harus mencari perspektif yang sama untuk mengurangi perbedaan dan bekerja dalam kerangka mutual understanding.

Analisis ekonomi politik yang digunakan dalam penelitian ini berlandaskan pada argumentasi bahwa idealnya lembaga-lembaga yang terlibat dalam proses penempatan dan 
perlindungan TKI menjalankan fungsinya seperti: pemerintah sebagai pihak yang memastikan bahwa proses penempatan telah berjalan sesuai prosedur sehingga TKI/PMI bisa diberikan perlindungan optimal di negara tujuan, perusahaan (Pelaksana Penempatan Tenaga Kerja Indonesia Swasta/PPTKIS) sebagai pihak yang merekrut telah memastikan bahwa TKI/PMI yang akan ditempatkan telah memenuhi standar dan kualifikasi yang dicantumkan dalam permintaan tenaga kerja (job order), dan TKI sebagai pihak yang akan/telah bekerja di luar negeri memiliki keterampilan yang sesuai dengan pekerjaannya. Kelembagaan pemerintah dan swasta yang membingkai proses migrasi kerja ini akan dielaborasi melalui kajian teoretik ekonomi politik dan temuan-temuan penelitian. Penelitian ini bertujuan untuk menggambarkan dan menganalisis pemenuhan hak-hak pekerja migran asal Sulawesi Selatan di Malaysia berdasarkan UU No. 39 Tahun 2004 pada masa pra-penempatan dan masa penempatan.

\section{METODE PENELITIAN}

Penelitian ini menggunakan tipe dan dasar metode kualitatif dengan pendekatan studi kasus yakni bagaimana pemenuhan hak-hak pekerja migran asal Sulawesi Selatan di Malaysia pada masa pra-penempatan dan masa penempatan. Satuan yang akan diteliti berasal dari unsur pemerintah, swasta dan masyarakat sipil. Pemilihan kasus berasal dari proses pada masa prapenempatan dan masa penempatan pekerja migran asal Sulsel.

Sumber data yang digunakan dalam penelitian ini terdiri atas data primer dan data sekunder. Data primer diperoleh peneliti dengan melakukan penelitian lapangan (field research) untuk mengumpulkan data-data wawancara dengan narasumber yang telah ditentukan. Sedangkan data sekunder diperoleh peneliti dengan melakukan telaah pustaka yakni mengumpulkan data dari buku, jurnal, media cetak dan elektronik, serta sumber informasi lainnya yang erat kaitannya dengan masalah penelitian.

Teknik analisis data dalam penelitian ini menggunakan analisis data kualitatif. Tahapan analisis data mengacu pada Miles \& Huberman dalam Silalahi (2012) yakni melakukan analisis dengan tiga alur kegiatan yang terjadi secara bersamaan, yaitu reduksi data, penyajian data, dan penarikan kesimpulan/verifikasi. Pelaksanaan secara bersamaan maksudnya adalah proses siklus dan interaktif pada saat sebelum, selama dan sesudah pengumpulan data dilakukan sejajar untuk membangun wawasan umum yang disebut analisis.

\section{HASIL DAN PEMBAHASAN}




\section{Hasil}

Pemenuhan hak-hak pekerja migran asal Sulawesi Selatan di Malaysia pada masa prapenempatan dan masa penempatan. Melalui ekonomi politik kelembagaan, kedua masa tersebut dilihat dari sisi peran pemerintah, interaksi pemerintah dan swasta dan peran masyarakat sipil. Pemerintah merupakan lembaga yang berperan sentral dalam pemenuhan hak-hak pekerja migran. Sebagaimana diamanatkan dalam UU No. 39 Tahun 2004 tentang Penempatan dan Perlindungan Tenaga Kerja Indonesia di Luar Negeri (PPTKILN). Pasal 5-7 menjelaskan tugas, tanggungjawab dan kewajiban pemerintah. Tugas pemerintah yakni mengatur, membina, melaksanakan, dan mengawasi penyelenggaraan penempatan dan perlindungan TKI di luar negeri. Sedangkan dalam melaksanakan tugasnya, pemerintah dapat melimpahkan sebagian wewenangnya dan/atau tugas perbantuan kepada pemerintah daerah sesuai dengan peraturan perundang-undangan. Tanggungjawab pemerintah yakni meningkatkan upaya perlindungan TKI di luar negeri.

Dalam menjalankan tugas dan tanggung jawab, pemerintah berkewajiban: (a) menjamin terpenuhinya hak-hak calon TKI/TKI, baik yang berangkat melalui pelaksana penempatan TKI, maupun yang berangkat secara mandiri; (b) mengawasi pelaksanaan penempatan calon TKI; (c) membentuk dan mengembangkan sistem informasi penempatan calon TKI di luar negeri; (d) melakukan upaya diplomatik untuk menjamin pemenuhan hak dan perlindungan TKI secara optimal di negara tujuan; dan (e) memberikan perlindungan kepada TKI selama masa sebelum pemberangkatan, masa penempatan, dan masa purna penempatan.

Tinjauan dari peran pemerintah dalam pemenuhan hak-hak pekerja migran asal Sulawesi Selatan di Malaysia pada masa pra-penempatan yakni: pemerintah berperan dalam pengesahan job order/demand letter melalui perwakilan RI di negara tujuan, dalam hal ini Konsulat RI di Tawau, selanjutnya penerbitan surat izin pengerahan (SIP) oleh Badan Nasional Penempatan dan Perlindungan TKI (BNP2TKI). Di tingkat pemerintah daerah, Dinas Tenaga Kerja Provinsi Sulawesi Selatan bertugas untuk menerbitkan surat pengantar rekrut (SPR) untuk mendistribusikan kuota perekrutan di tiap daerah. Peran pemerintah kabupaten/kota dalam hal ini yang diteliti yakni kota Makassar, kabupaten Gowa dan kota Pare-Pare yakni memberikan pelayanan terhadap TKI/PMI. Namun pemerintah kabupaten/kota masih belum responsif.

Interaksi pemerintah dan swasta dapat ditinjau dari kewajiban Pelaksana Penempatan TKI Swasta (PPTKIS) untuk memiliki Surat Izin Pelaksana Penempatan Tenaga Kerja 
Indonesia (SIPPTKI) dari pemerintah dengan seperangkat persyaratan "finansial" untuk merekrut TKI, selanjutnya PPTKIS mendampingi majikan/pengguna TKI di Malaysia untuk mempersiapkan job order/demand letter serta dokumen pendukung lainnya. PPTKIS lalu mengurus SIP ke BNP2TKI melalui BP3TKI dengan sejumlah persyaratan. . Kemudian PPTKIS mengurus SPR ke Disnakertrans Prov. Sulsel dengan menyertakan SIP. Disnakertrans Provinsi Sulsel mengalokasikan daerah rekrut yang menjadi batasan bagi PPTKIS. PPTKIS juga berkewajiban mengikutkan TKI untuk diberikan Pembekalan Akhir Pemberangkatan (PAP) oleh pemerintah melalui BP3TKI/P4TKI dan membekali TKI dengan E-KTKLN yang diterbitkan pemerintah sebagai identitas TKI yang legal dan prosedural. Selanjutnya, peran masyarakat sipil pada masa pra-penempatan masih terbatas dan LSM yang aktif masih berpusat di Jakarta (Ibukota). Migrant CARE (LSM) menyatakan bahwa TKI Sulsel relatif tidak ada masalah. Sedangkan peran LSM di Sulsel belum terlihat.

Peran pemerintah dalam pemenuhan hak-hak pekerja migran asal Sulawesi Selatan di Malaysia pada masa penempatan dijalankan oleh perwakilan Republik Indonesia di Malaysia, dalam hal ini Konsulat RI di Tawau. KRI Tawau memiliki prioritas untuk memberikan pelayanan dan perlindungan bagi TKI. Sedangkan peran pemerintah Malaysia dijalankan oleh Jabatan Tenaga Kerja Sabah yang bertugas mengawasi pekerja asing, termasuk TKI. Pemerintah Malaysia memiliki mekanisme untuk melindungi pasar tenaga kerja lokal, sehingga lapangan kerja dengan kategori 3D (dirty, dangerous, difficult) yang tidak diminati pekerja lokal dibuka untuk pekerja asing. Kebijakan ketenagakerjaan yang mengatur pekerja lokal dan pekerja asing di Sabah mengacu pada Sabah Labour Ordinance.

Interaksi pemerintah dan swasta pada masa penempatan dapat dikaji dari majikan/pengguna yang mempekerjakan TKI asal Sulsel tidak hanya swasta, tetapi juga perusahaan milik pemerintah. KRI Tawau sebagai perwakilan pemerintah Indonesia di Malaysia melakukan pendataan terhadap pekerja perkebunan di wilayah Tawau dan melakukan kunjungan ke ladang, tugas lainnya dijalankan seperti menerima pengaduan melalui telepon, faks, SMS, email, maupun datang ke kantor, apabila ada permasalahan dengan majikan. KRI Tawau juga memiliki Satgas Perlindungan WNI/TKI untuk melayani permasalahan TKI dan memberikan pelayanan pengembalian tuntutan gaji WNI/TKI. Sedangkan pemerintah Malaysia ikut memberikan pengawasan kepada pekerja maupun majikan melalui JTK Sabah dengan melakukan inspeksi ke lapangan maupun menerima aduan di kantor. Dalam piagam pelanggan JTK Sabah mengatur kepentingan majikan dan pekerja dan menciptakan hubungan yang harmonis. 
Peran masyarakat sipil pada masa penempatan ditinjau dari realita di lapangan yakni secara umum serikat pekerja migran tidak diizinkan di Malaysia dikarenakan pekerja migran dianggap ancaman bagi pekerja asal Malaysia. Sehingga organisasi TKI di Malaysia masih terbatas dengan kegiatan keagamaan, paguyuban daerah dan kesenian. Sedangkan kegiatan penyediaan informasi ketenagakerjaan maupun proses migrasi belum diwadahi. Lebih spesifik di Sabah, pekerja migran asal Sulsel memiliki mekanisme tersendiri untuk menyelesaikan masalah dengan majikan dikarenakan lingkungan kerja yang berkelompok dengan jumlah yang cukup besar.

\section{Pembahasan}

Penelitian ini menunjukkan pemenuhan hak-hak pekerja migran asal Sulawesi Selatan pada masa pra-penempatan dan masa penempatan berkaitan erat dengan kapasitas kelembagaan dalam menerapkan kebijakan terhadap TKI yang menjalankan kegiatan ekonomi. Pemaparan hasil di atas bersesuaian dengan pendekatan peran hukum dalam ekonomi politik kelembagaan yang dikemukakan oleh Commons, Coase dan North dalam Deliarnov (2006). Pakar kelembagaan menyatakan bahwa ekonomi pasar tidak tercipta dengan sendirinya. Ekonomi pasar perlu memenuhi prasyarat tegaknya suatu institusi yang dapat mengatur pola interaksi beberapa aktor dalam suatu arena transaksi yang disepakati bersama. Kelembagaan dilihat dari sisi hukum menentukan dan/atau mewarnai transaksi, terutama melalui aturan main yang berlaku, sekaligus juga mengatur kelompok atau agen ekonomi untuk mewujudkan kontrol kolektif terhadap transaksi.

Pandangan yang dikemukakan oleh Commons, Coase dan North dalam Deliarnov (2006) mendukung asumsi peneliti bahwa pemenuhan hak-hak pekerja migran asal Sulawesi Selatan perlu di analisis dari sisi ekonomi politik kelembagaan, khususnya dalam melihat peran hukum/kebijakan. Peran pemerintah, interaksi pemerintah dan swasta, serta peran masyarakat sipil di atas menunjukkan bahwa pemerintah menerapkan seperangkat aturan untuk dipenuhi oleh PPTKIS (swasta). Hal ini direspon dengan baik oleh PT. Amalindo Bhakti Persada, salah satu PPTKIS yang berkantor pusat di Sulawesi Selatan. Perusahaan ini secara administratif berupaya untuk memenuhi ketentuan pemerintah. Selain itu, pemerintah Malaysia yang merupakan negara penempatan turut mengawasi pekerja migran Indonesia yang akan masuk ke negaranya melalui sistem tapisan yang dilakukan oleh majikan maupun pihak Jabatan Imigresen. Hal ini membentuk sistem ekonomi politik kelembagaan yang kondusif sehingga sinergi pemerintah dan swasta dapat terjaga. 
Model interaksi yang terbentuk dari analisis ekonomi politik dalam pemenuhan hakhak pekerja migran asal Sulawesi Selatan pada masa pra-penempatan berdasarkan identifikasi Bustanul Arifin dalam Deliarnov yakni model invisible hand. Ditinjau dari sisi sistem hukum, pemerintah menyediakan sarana dan prasarana dasar seperti pelayanan penempatan TKI. Sistem hukum ditegakkan dan diterapkan kepada swasta untuk melaksanakan penempatan TKI ke Malaysia sesuai ketentuan. Sedangkan tinjauan peraturan/regulasi pemerintah mengeluarkan peraturan dan ikut mematuhi peraturan. Peran dunia usaha (swasta) dalam ekonomi cukup besar, sehingga dapat membuka kesempatan kerja ke luar negeri bagi masyarakat.

Pemenuhan hak-hak pekerja migran asal Sulawesi Selatan pada masa penempatan juga menunjukkan bahwa peran hukum dalam ekonomi politik kelembagaan yang dikemukakan oleh Commons, Coase dan North dalam Deliarnov (2006) sebagaimana yang telah diidentifikasi pada masa pra-penempatan juga terlihat pada masa penempatan. Masing-masing aktor menerapkan aturan main, seperti Konsulat RI Tawau yang menjalankan fungsi kelembagaannya sebagai perwakilan pemerintah Indonesia di negara penempatan yang menjalankan kebijakan/hukum berdasarkan arahan dari Kementerian Luar Negeri RI. Demikian juga dengan pemerintah Malaysia yang telah menerapkan mekanisme tapisan sejak masa pra-penempatan, semakin mendominasi aturan main dikarenakan pekerja migran Indonesia berada dalam wilayah kekuasaan hukumnya, sehingga pekerja migran Indonesia yang dikategorikan pekerja asing di Malaysia wajib mematuhi aturan di Sabah Malaysia dengan mengacu pada aturan pokok Sabah Labour Ordinance. Chuan (2013), menyatakan bahwa ada aturan yang berlaku di Sabah secara khusus tetapi ada juga hukum perburuhan/ketenagakerjaan yang berlaku secara umum di Malaysia.

Fakta di atas semakin menegaskan asumsi peneliti terkait kuatnya hubungan antara peran hukum/kebijakan dalam ekonomi politik kelembagaan dengan pemenuhan hak-hak pekerja migran asal Sulawesi Selatan. Seyogyanya aturan main dalam ekonomi politik kelembagaan memberikan rasa aman dan nyaman, sehingga tujuan ekonomi yang menjadi luaran dari proses migrasi pekerja dapat tercapai dan kelembagaan yang terlibat dalam proses tersebut juga dapat memperoleh manfaat.

Pernyataan jika pelaku ekonomi (TKI) dari aturan main yang telah ditetapkan melakukan pelanggaran/penyimpangan, maka akan menghadapi resiko. Pernyataan teoretis ini ditanggapi pada penjelasan di atas bahwa hadirnya kebijakan/hukum tersebut merupakan respon atas terjadinya kasus yang berkaitan dengan TKI/PMI yang berkembang ke arah 
perdagangan orang (trafficking), dikarenakan sebelum hadirnya kebijakan tersebut penempatan TKI hanya mengacu pada Ordonansi tentang Pengerahan Orang Indonesia Untuk Melakukan Pekerjaan di Luar Indonesia (Staatsblad Tahun 1887 Nomor 8) dan Keputusan Menteri serta peraturan pelaksanaannya yang masih sangat sederhana dan belum komprehensif.

Hal ini sejalan dengan semangat yang dinyatakan dalam penjelasan UU No. 39 Tahun 2004 yang menyatakan pada hakekatnya ketentuan ketentuan hukum yang dibutuhkan dalam masalah ini adalah ketentuan-ketentuan yang mampu mengatur pemberian pelayanan penempatan bagi tenaga kerja secara baik. Pemberian pelayanan penempatan secara baik didalamnya mengandung prinsip murah, cepat, tidak berbelit belit dan aman. Pengaturan yang bertentangan dengan prinsip tersebut memicu terjadinya penempatan tenaga kerja ilegal yang tentunya berdampak kepada minimnya perlindungan bagi tenaga kerja yang bersangkutan. Sejalan dengan semakin meningkatnya tenaga kerja yang ingin bekerja di luar negeri dan besarnya jumlah TKI yang sekarang ini bekerja di luar negeri, meningkat pula kasus perlakuan yang tidak manusiawi terhadap TKI baik di dalam maupun di luar negeri. Kasus yang berkaitan dengan nasib TKI semakin beragam dan bahkan berkembang ke arah perdagangan manusia yang dapat dikategorikan sebagai kejahatan terhadap kemanusiaan.

Pekerja migran asal Sulawesi Selatan yang mematuhi aturan main sejak masa prapenempatan dapat bekerja dengan tenang dan aman di masa penempatan hingga kontrak kerja berakhir. Sehingga tujuan untuk memaksimalkan keuntungan ekonomi dari proses migrasi dapat tercapai. Sedangkan bagi TKI/PMI yang menempuh jalur non-prosedural mendapatkan akses yang minim terhadap lembaga-lembaga yang dapat menjamin pemenuhan hak-haknya seperti perwakilan RI maupun jabatan tenaga kerja. Akibatnya tanpa kehadiran institusi yang melindungi hak-haknya, biaya transaksi menjadi tinggi. Selain itu, TKI/PMI non-prosedural menghadapi resiko penipuan, pemerasan, ancaman fisik dan bentuk-bentuk ketidaksiapan lainnya. Hal tersebut terjadi pada TKI/WNI yang dideportasi setiap bulannya kembali ke Indonesia.

Walau demikian, upaya pemerintah untuk memberikan perlindungan kepada TKI/PMI prosedural maupun non-prosedural harus dioptimalkan sebagai bentuk perlindung WNI di luar negeri. Iskandar (2011), menyatakan semua pihak harus didorong untuk mempertimbangkan pemanfaatan hukum HAM internasional bagi pemajuan HAM, khususnya bagi pekerja migran Indonesia dan penciptaan sebuah manajemen migrasi yang baik. Usulan ini tidak bisa dilepaskan dari fakta yang menunjukkan bahwa baik pemerintah Indonesia 
maupun para pihak yang terlibat dalam advokasinya belum mampu memanfaatkannya secara maksimal. Yuwono (2011), juga menyatakan bahwa dalam melakukan pembaruan hukum tentang TKI juga harus berpedoman dengan hukum internasional, yakni nilai-nilai konvensi internasional yang berkaitan dengan perlindungan terhadap buruh migran dan keluarganya.

Model interaksi yang terbentuk dari analisis ekonomi politik dalam pemenuhan hakhak pekerja migran asal Sulawesi Selatan pada masa penempatan berdasarkan identifikasi Bustanul Arifin dalam Deliarnov yakni model invisible hand. Ditinjau dari sisi sistem hukum, pemerintah Indonesia melalui perwakilannya maupun pemerintah Malaysia menyediakan sarana dan prasarana dasar seperti seperangkat pelayanan untuk perlindungan TKI. Pemerintah Indonesia menggunakan perangkat hukum setempat untuk menuntut hak-hak TKI yang tidak dipenuhi. Sedangkan pemerintah Malaysia menggunakan aturannya untuk mengawasi pekerja maupun majikan sehingga keduanya wajib mematuhi aturan tersebut. Sedangkan tinjauan peraturan/regulasi, pemerintah mengeluarkan peraturan dan ikut mematuhi peraturan. Pemerintah Indonesia menghormati peraturan pemerintah Malaysia dan perusahaan Malaysia yang ingin mendapatkan jaminan terhadap TKI yang dipekerjakan juga menempuh aturan yang ditetapkan oleh pemerintah Indonesia saat pra-penempatan. Kebutuhan dunia usaha terhadap TKI yang cukup tinggi atas pekerja sektor perkebunan membuka akses bagi TKI untuk ditempatkan pada sektor pekerjaan tersebut.

\section{KESIMPULAN}

Pemenuhan hak-hak pekerja migran asal Sulawesi Selatan pada masa pra-penempatan berdasarkan UU No. 39 Tahun 2004 bersesuaian dengan pendekatan peran hukum dalam ekonomi politik kelembagaan. Hal ini terlihat dari seperangkat aturan yang merupakan turunan dari UU No. 39 Tahun 2004 ditetapkan oleh pemerintah sebagai aturan main bagi swasta (PPTKIS) untuk menempatkan TKI. Sedangkan pemenuhan hak-hak pekerja migran asal Sulawesi Selatan pada masa penempatan berdasarkan UU No. 39 Tahun 2004 juga menunjukkan pendekatan yang sama dengan masa pra-penempatan yakni peran hukum dalam ekonomi politik kelembagaan. Perwakilan pemerintah Indonesia di Tawau menjalankan kebijakan/hukum berdasarkan arahan dari Kementerian Luar Negeri RI yang bersumber dari UU No. 37 Tahun 1999 terkait pelaksanaan hubungan luar negeri dan UU No. 39 Tahun 2004 terkait perlindungan TKI di masa penempatan kemudian diturunkan lagi dalam PP No. 3 Tahun 2013 yang mengatur lebih detil perlindungan yang diberikan. 


\section{DAFTAR PUSTAKA}

Caporaso, James. A. dan David P. Levine. (2008). Teori-Teori Ekonomi Politik. Yogyakarta: Pustaka Pelajar.

Chuan, Goh Chen. (2013). Guide to the Employment Act and Labour Laws of Malaysia. Selangor: Leeds Publications.

Deliarnov. (2006). Ekonomi Politik. Jakarta: Penerbit Erlangga.

Detik Finance. (2014). Pekerja Perkebunan di Malaysia Didominasi TKI, Ini Alasannya. Diakses 2 Maret 2016. Available from: http://finance.detik.com/read/2014/11/08/173138/2742842/4/pekerja-perkebunan-dimalaysia-didominasi-tki-ini-alasannya.

Husna, Faizah Khotimatul. (2013). Kajian Kebijakan Pemerintah dalam Penempatan dan Perlindungan Tenaga Kerja Indonesia. Tesis. Universitas Gadjah Mada.

Iskandar, Pranoto. (ed.). (2011). Standar Internasional Migrasi Ketenagakerjaan Berbasis HAM. Cianjur: IMR Press

Islam M. R. (2013). Partnership Research Between Malaysia and Indonesia: A Case of Labor Welfare. Social Research Reports, 25:7-8.

Kardina. (2015). Pelanggaran Malaysia terhadap Standar HAM Convention on the Elimination of All Forms of Discrimination Against Women dalam Isu Kekerasan Migrant Domestic Worker Indonesia. Tesis. Universitas Gadjah Mada.

Masrie, Aspiannor. (2015). Analisis Kebijakan Susilo Bambang Yudhoyono dalam Menangani Masalah Tenaga Kerja Indonesia di Malaysia dalam Perspektif Ekonomi Politik. Tesis. Universitas Hasanuddin.

Nasir Badu, Muhammad (ed.). (2015). Proceeding of International Seminar Democracy and Election: Solution for Establishing Good Governance. Yogyakarta: LeutikaBooks.

Silalahi, Ulber. (2012). Metode Penelitian Sosial. Bandung: PT. Refika Aditama.

Yustika, Ahmad Erani. (2009). Ekonomi Politik: Kajian Teoretis dan Analisis Empiris. Yogyakarta: Pustaka Pelajar.

Yuwono, Ismantoro Dwi. (2011). Hak dan Kewajiban Tenaga Kerja Indonesia di Luar Negeri. Yogyakarta: Penerbit Pustaka Yustisia.

Zulfikar, Achmad. (2015). Rasionalitas Ekonomi Politik dalam Ratifikasi Konvensi Internasional Perlindungan Hak Pekerja Migran Tahun 2012. The Politics: Jurnal Magister Ilmu Politik Universitas Hasanuddin Vol. 1 No. 1. 